\title{
EFFECT OF REPEATED COLD WATER SWIMMING EXERCLSE ON ADAPTIVE CHAMGES IN BODY WEIGHT IN OLDER RATS
}

\author{
Iwona Bryczkowska, , A, B, C, D Irena Baranowska-Bosiacka, ${ }^{2, B}$ Anna Lubkowska1, A, B, C, D, E \\ ${ }^{1}$ Department of Functional Diagnostics and Physical Medicine, Faculty of Health Sciences, Pomeranian Medical University in Szczecin, Poland \\ ${ }^{2}$ Department of Biochemistry, Faculty of Medicine with English Language Teaching Department, Pomeranian Medical University in Szczecin, \\ Poland \\ ${ }^{\text {A }}$ Study Design; ${ }^{\text {B }}$ Data Collection; ${ }^{\mathrm{C}}$ Statistical Analysis; ${ }^{\mathrm{D}}$ Manuscript Preparation; ${ }^{\mathrm{E}}$ Funds Collection
}

\author{
Address for corpespondence: \\ Anna Lubkowska \\ Pomeranian Medical University in Szczecin, Faculty of Health Sciences \\ Department of Functional Diagnostics and Physical Medicine \\ Żołnierska 54, 71-210 Szczecin, Poland \\ E-mail: annalubkowska@gmail.com
}

\begin{abstract}
Ahstract The aim of this study was verification whether an 8-week-long swimming exercise training would induce adaptive changes in body weight in rats and whether possible changes would depend on aquatic environment temperature and animal sex. The exercisetrained groups swam 4 minutes a day, five days a week during eight week of housing. Exercise was performed by swimming in glass tanks containing tap water maintained according to group at $5 \pm 2^{\circ} \mathrm{C}$ (cold group) and $36 \pm 2^{\circ} \mathrm{C}$ (thermal neutral group). Before and after each week of the experiment, rats were weighed. When comparing the nature of changes in the body weight of rats exposed to swimming exercise training in cold water, attention should be paid to their dependence on sex. There were statistically significant changes in the nature of changes in body weight between male rats and female rats of the cold group $\left(5^{\circ} \mathrm{C}\right)$ as early as experimental week 2 until the end of the experiment $(p<0.001)$. Interestingly, the females exposed to swimming exercise training at $5^{\circ} \mathrm{C}$ were the only group in which an increase in body weight occurred during experimental week 8 in relation to baseline values.
\end{abstract}

Key WOrlds cold-acclimation, exercise training, swimming exercise, body weight, rats

\section{Introduction}

One of the most important processes that allow an organism to survive in a changing environment is the ability to regulate body temperature. In warm-blooded animals, the ability to maintain a relatively constant internal body temperature is a prerequisite for their proper functioning (Moran, Mendal, 2002). Exposure to cold is one of the strongest physiological and psychological environmental stressors and leads to significant physiological responses of the body. In particular, the aquatic environment is a challenge for thermoregulation processes of a living organism. Cold water immersion leads to immediate physiological responses collectively known as the "cold shock response", as well as to long-term physiological, biochemical, hormonal and metabolic responses and cardiovascular system response, documented in the experiments on both animals and humans (Kolettis, Kolettis, 
2003; Akhalaya, Platonov, Baizhumanov, 2006; Agrawal, Jaggi, Singh, 2011). During a prolonged exposure of the organism to extremely low temperatures, especially in the aquatic environment, metabolic heat production is unable to compensate its loss (Teległów et al., 2008). In the aquatic environment at $5^{\circ} \mathrm{C}$, the resting rectal temperature decreases within 20 minutes by $1.2^{\circ} \mathrm{C}$, whereas at the same time it decreases by $1.8^{\circ} \mathrm{C}$ during a swimming exercise (Keatinge, 1961). The heat loss in water is 250 times higher than in air, at the same time water as a thermal energy carrier has a heat capacity 4 times higher than air, while its thermal conductivity is 25 times higher that that of air. Consequently, hypothermia due to immersion in water takes place 2-3 times faster than in the atmospheric air with a comparable temperature (Straburzyńska-Lupa, Straburzyński, 2008).

The response of organism to exercise in cold water may depend largely on such individual characteristics as the metabolic rate and the volume of subcutaneous adipose tissue which is an important insulative factor due to low thermal conductivity and vascularisation. Research shows that subcutaneous adipose tissue being $1 \mathrm{~mm}$ thick allows the body to tolerate well its cooling by $1-2^{\circ} \mathrm{C}$ (Wilmore, Costill, 2008; Chukroun, Varene, 1990). Intensive physical exercise in cold water environment, due to excessive heat loss to external environment, leads to increased secretion of the hormones that stimulate metabolism; the sympathetic-adrenal-medullary axis is being stimulated, as well as noradrenalin, adrenalin and cortisol secretion. Both cold and physical exercise are stress factors that stimulate the sympathetic system through which the mechanism of shivering and non-shivering muscular thermogenesis are activated, also taking place in adipose tissue, inducing increased heat production. As skeletal muscle makes up nearly $40 \%$ of the body weight and is aerobically active, it is a primary contributor to thermogenesis during cold exposure via both shivering (ST) and non-shivering thermogenesis (NST) (Block, 1994). In rodents, the initial reliance on shivering thermogenesis is replaced over time with NST by the BAT (brown adipose tissue) (Sellers, Scott, Thomas, 1954). There is some evidence that cold stimulation, as well as cold swimming, affects lipoprotein metabolism (Tsopanakis, Tesserommatis, 1991; Lubkowska et al., 2010a). WAT (white adipose tissue) and BAT are two main types of fat in mammals. WAT is the primary energy depot that stores energy as triglyceride-enriched lipid droplets. By contrast, BAT is considered as an efficient energy dispenser that consumes chemical energy toward thermogenesis (Cannon, Nedergaard, 2004; Richard D, Picard, 2011; Kozak, Harper, 2000). In order to remain normothermic during the periods of cold exposure warm-blooded organisms must produce metabolic heat. Because small animals have the highest ratio of heat-dissipating surface area to heat-storing volume, it is not surprising that they have evolutionarily retained (or developed) a separate tissue for thermogenesis. This thermogenic task in small placental mammals is primarily accomplished by brown adipose tissue. In warm-blooded mammals BAT is regarded as the primary effector organ of non-shivering thermogenesis (Villarin, Schaeffer, Markle, Lindstedt, 2003; Foster, Frydman, 1978). The body defends itself against heat losses in two ways: by increasing the insulative properties of body surface area and through thermogenesis. In cold environments, the integument primarily acts as an insulator, whereas in high temperatures it is the main route of removing heat from deeper tissues of the body due to changes in blood flow (Benarroch, 2007).

It seems important to determine the scope of adaptive changes that occur in the organism following the exposure to cold and physical exercise in cold environment, also the aquatic one. Our previous studies have shown that repeated exposure to cold stimulates the immune system, improves the activity of antioxidant system, and modifies the lipid profile (Lubkowska, Szygula, Klimek, Torii, 2010b; Lubkowska et al., 2013; Lubkowska, Dołęgowska, Szyguła, 2012). 
If exposure to cold persists long enough to produce adaptive mechanisms, changes in body composition may occur, primarily the insulative subcutaneous fat layer may increase. Given that both physical exercise and cold water immersion are the factors that intensify metabolism, we decided to verify in this study whether an 8-week-long swimming exercise training would induce adaptive changes in body weight in rats and whether possible changes would depend on aquatic environment temperature and animal sex.

\section{Material and methods}

Sixty-four 15-month-old male and female albino Wistar rats were randomly allocated to three groups. The first group (old sedentary control), kept in cages at room temperature, was composed of male $(n=8)$ and female $(n=8)$ rats. The second group included old-trained animals, swimming in cold water $\left(5 \pm 2^{\circ} \mathrm{C}\right.$; 12 male rats; 12 female rats). The last group were animals swimming in thermal neutral water $\left(36 \pm 2^{\circ} \mathrm{C}\right.$; 12 male rats; 12 female rats). All rats were given standard rat chow and tap water ad libitum and were housed two to four per cage $\left(23 \pm 2^{\circ} \mathrm{C}, 40 \%\right.$ air humidity, 12-hour light/dark cycle). One animal from old sedentary control and three animals from old-trained group died before the end of the experiment. The study was approved by the Local Ethical Committee on Animal Experimentation (Decision No. 38/2015).

The exercise-trained groups swam 4 minutes a day, five days a week during eight week of housing (between 09:00 and 11:00 h on each training day). The control rats were housed under the same conditions as the swimming rats and they were handled as often as the exercise group. Exercise was performed by swimming in glass tanks (length $100 \mathrm{~cm}$, width $50 \mathrm{~cm}$, depth $50 \mathrm{~cm}$ ) containing tap water maintained according to group at $5 \pm 2^{\circ} \mathrm{C}$ (cold group) and $36 \pm 2^{\circ} \mathrm{C}$ (thermal neutral group). A maximum of only two rats was allowed to swim together. The duration of the first swimming experience was limited to $2 \mathrm{~min}$ and increased by $0.5 \mathrm{~min}$ daily in the first week until it reached 4 minutes. Before and after each week of the experiment, rats were weighed. At the beginning and after 8 weeks of the experiment, the resting rectal temperature of rats was measured. Additionally, in the fourth week of experiment, we examined the temperature effects of a single swimming exercise session in all animals. All protocol of experiment was presented in Table 1.

Statistical analysis was conducted with STATISTICA software package (version $12.5 \mathrm{PL}$ ). The normality of distribution of the parameters being analysed was determined using the Shapiro-Wilk test. In the case of data demonstrating that their distribution differed from normal one, a Friedman's ANOVA and a non-parametric MannWhitney $U$ test were used. For all statistical analyses mentioned above, the accepted level of significance was defined as $p<0.05$.

Table 1. Summary data related to swimming exercise training of rats, including group size, duration of swimming exercise and water temperature

\begin{tabular}{|c|c|c|c|c|c|c|}
\hline \multirow[t]{2}{*}{ Sex } & $\mathrm{N}$ & \multirow[t]{2}{*}{$\begin{array}{c}\text { Age } \\
\text { (months) }\end{array}$} & \multirow[t]{2}{*}{$\begin{array}{l}\text { Duration of } \\
\text { experiment }\end{array}$} & \multirow{2}{*}{$\begin{array}{c}\text { Water } \\
\text { temperature } \\
5 \pm 2^{\circ} \mathrm{C}\end{array}$} & \multicolumn{2}{|c|}{$\begin{array}{c}\text { Duration } \\
\text { of swimming exercise }\end{array}$} \\
\hline & 10 & & & & 1st week & 2nd-8th week \\
\hline \multirow{3}{*}{$\delta$} & 12 & & & $36 \pm 2^{\circ} \mathrm{C}$ & $(1-4 \mathrm{~min})$ & (4 min) \\
\hline & 7 & 15 & 8 weeks & \multicolumn{3}{|c|}{ Non-swimming control group } \\
\hline & 12 & 15 & (5 day/week) & $5 \pm 2^{\circ} \mathrm{C}$ & 1st week & 2nd-8th week \\
\hline \multirow[t]{2}{*}{ 우 } & 11 & & & $36 \pm 2^{\circ} \mathrm{C}$ & $(1-4 \min )$ & (4 min) \\
\hline & 8 & & & \multicolumn{3}{|c|}{ Non-swimming control group } \\
\hline
\end{tabular}




\section{Resullts}

During the study, significant changes in the body weight of rats exposed to swimming exercise training were observed. Table 2 summarises the changes in the body weight of rats during the experiment in relation to baseline values in respective test groups and the control group whereas Table 3 presents both the differences in body weight changes between respective weeks of swimming exercise training for the test groups and the significance of intergroup differences of these changes.

When analysing the group of male rats exposed to swimming exercise training in water at $5^{\circ} \mathrm{C}$, a decrease in their body weight was observed as early as the first week of swimming. The highest decrease in body weight, by $32.25 \mathrm{~g}$ on average, was recorded between experimental week 1 and $2\left({ }^{*} \Delta T_{1}-T_{2}\right.$; Table 3$)$; the rats were characterised then by body weight being lower by $46.75 \mathrm{~g}$ in relation to baseline values (Table 2). Next, in successive weeks, their body weight remained at a comparable level, with minor fluctuations in its increase and decrease, but at the end of the training it was still significantly lower, by $45 \pm 38.56 \mathrm{~g}$ on average, than baseline values $(p<0.05)$.

Tahle 2. Changes in the body weight of rats during successive weeks of swimming exercise training

\begin{tabular}{|c|c|c|c|c|c|c|}
\hline \multirow{2}{*}{$\mathrm{BW}[\mathrm{g}]$} & $\begin{array}{l}\partial^{2}\left[5^{\circ} \mathrm{C}\right] \\
n=10\end{array}$ & $\begin{array}{l}3\left[36^{\circ} \mathrm{C}\right] \\
n=12\end{array}$ & $\begin{array}{c}\left.\text { C }^{\circ} n r^{\circ}\right)^{\top} \\
n=7\end{array}$ & $\begin{array}{l}+\left[5^{\circ} \mathrm{C}\right] \\
\mathrm{n}=12\end{array}$ & $\begin{array}{c}q\left[36^{\circ} \mathrm{C}\right] \\
\mathrm{n}=11\end{array}$ & $\begin{array}{c}\text { C }^{\circ} \text { ntr }{ }^{\circ} \mid \text { P } \\
n=8\end{array}$ \\
\hline & \multicolumn{6}{|c|}{$\overline{\mathrm{x}}$} \\
\hline$\Delta \mathrm{T}_{0}-\mathrm{T}_{1}$ & $-14.5 \pm 17.16$ & $-19.25 \pm 11.15$ & $-5.63 \pm 25.28$ & $-8.25 \pm 12.49$ & $\begin{array}{c}-4.75 \pm 7.52 \\
* * * \\
*\end{array}$ & $-5.00 \pm 8.86$ \\
\hline$\Delta \mathrm{T}_{0}-\mathrm{T}_{2}$ & $\begin{array}{c}-46.75 \pm 19.35 \\
{ }^{*} \Delta \mathrm{T}_{0}-\mathrm{T}_{1}\end{array}$ & $\begin{array}{c}-19.25 \pm 11.15 \\
* * * * 5^{\circ}\end{array}$ & $\begin{array}{c}+10.00 \pm 16.26 \\
* * * \pi 5^{\circ} \\
* * * \\
{ }^{*} 36^{\circ}\end{array}$ & $\begin{array}{c}-8.25 \pm 12.49 \\
* * * \star \\
>5^{\circ}\end{array}$ & 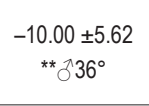 & $\begin{array}{c}+4.38 \pm 16.35 \\
* 05^{\circ} \\
{ }^{*}+36^{\circ}\end{array}$ \\
\hline$\Delta \mathrm{T}_{0}-\mathrm{T}_{3}$ & $-37.75 \pm 23.20$ & $\begin{array}{c}-9.75 \pm 13.81 \\
* * * \quad 5^{\circ}\end{array}$ & $\begin{array}{c}-5.63 \pm 27.96 \\
* * \approx 5^{\circ}\end{array}$ & \begin{tabular}{c}
$+0.25 \pm 11.75$ \\
$* * \star \star$ \\
\hdashline $5^{\circ}$
\end{tabular} & $-1.50 \pm 34.53$ & $-1.25 \pm 15.76$ \\
\hline$\Delta \mathrm{T}_{0}-\mathrm{T}_{4}$ & $-37.25 \pm 31.81$ & $\begin{array}{c}-20.25 \pm 17.28 \\
* * \pi 5^{\circ}\end{array}$ & $\begin{array}{c}-1.88 \pm 55.96 \\
* * \pi 5^{\circ}\end{array}$ & $\begin{array}{c}+4.50 \pm 8.57 \\
{ }^{* * *}{ }^{\circ} 5^{\circ} \\
{ }^{* *} \Delta \mathrm{T}_{0}-\mathrm{T}_{1} \\
{ }^{* *} \Delta \mathrm{T}_{0}-\mathrm{T}_{2}\end{array}$ & $\begin{array}{c}-10.75 \pm 23.07 \\
* * * 5^{\circ} \\
* * 36^{\circ}\end{array}$ & $\begin{array}{c}-8.75 \pm 10.26 \\
* * 05^{\circ}\end{array}$ \\
\hline$\Delta \mathrm{T}_{0}-\mathrm{T}_{5}$ & $\begin{array}{c}-45.00 \pm 30.35 \\
{ }^{*} \Delta T_{0}-T_{1}\end{array}$ & $\begin{array}{c}-19.00 \pm 16.35 \\
* \star \star \\
{ }^{\star} 5^{\circ}\end{array}$ & $\begin{array}{c}-9.38 \pm 25.13 \\
* * 5^{\circ}\end{array}$ & $\begin{array}{c}+4.50 \pm 9.58 \\
* * * \\
{ }^{*} 5^{\circ} \\
{ }^{* *} \Delta \mathrm{T}_{0}-\mathrm{T}_{1} \\
{ }^{* *} \Delta \mathrm{T}_{0}-\mathrm{T}_{2} \\
\end{array}$ & $\begin{array}{c}-18.25 \pm 21.35 \\
* * * \circ 5^{\circ}\end{array}$ & $\begin{array}{c}-4.38 \pm 12.66 \\
* \circ 5^{\circ}\end{array}$ \\
\hline$\Delta \mathrm{T}_{0}-\mathrm{T}_{6}$ & $-37.50 \pm 33.54$ & $\begin{array}{c}-17.75 \pm 21.24 \\
* * 5^{\circ}\end{array}$ & $\begin{array}{c}-5.00 \pm 13.89 \\
* * 5^{\circ}\end{array}$ & $\begin{array}{c}+9.25 \pm 7.67 \\
{ }^{* * *} 5^{\circ} \\
{ }^{* *} \Delta T_{0}-T_{1} \\
{ }^{* *} \Delta T_{0}-T_{2}\end{array}$ & $\begin{array}{c}-17.75 \pm 22.91 \\
* * * \circ 5^{\circ}\end{array}$ & $\begin{array}{c}-0.63 \pm 13.21 \\
* \circ 5^{\circ} \\
* \quad 36^{\circ}\end{array}$ \\
\hline
\end{tabular}

BW - body weight; ${ }^{*} p<0.05,{ }^{* *} p<0.01,{ }^{* * *} p<0.001$.

In the case male rats swimming in water at $36^{\circ} \mathrm{C}$, a decrease in their body weight was also observed as early as experimental week 1 , by $19.25 \mathrm{~g}$ on average, and this was the highest decrease observed during the whole experiment (Table 3). Next, their body weight remained at a comparable level in successive weeks, with minor fluctuations in its increase and decrease. The body weight of rats of this group at the end of the experiment was lower, by $28 \pm 22.68 \mathrm{~g}$ on average, than baseline values (Table 2 ). When comparing the dynamics of changes in body weight between the groups of tested male rats, it was observed that a decrease in body weight in the first two weeks 
was higher in the group of male rats swimming in water at $5^{\circ} \mathrm{C}$, while in the next weeks it already demonstrated similar trends (Table 2). It should be noted that body weight in the control group of rats during the experiment remained at a comparable level in successive weeks, with minor fluctuations in its increase and decrease. Only experimental week 2 was characterised by a significant increase in body weight compared to other experimental weeks ( ${ }^{*} \Delta T_{1}-T_{2}$, Table 3). Significant differences in the course of body weight changes between the control group and the test groups were observed as early as experimental week 2 , but they were significantly higher in the group exposed to swimming exercise training in water at $5^{\circ} \mathrm{C}$ (Table 2).

Tahle 3. Comparison of the significance of differences in body weight changes between groups

\begin{tabular}{|c|c|c|c|c|c|c|}
\hline \multirow[t]{2}{*}{$\mathrm{BW}[\mathrm{g}]$} & $\begin{array}{l}3\left[5^{\circ} \mathrm{C}\right] \\
\mathrm{n}=10\end{array}$ & $\begin{array}{c}3\left[36^{\circ} \mathrm{C}\right] \\
n=12\end{array}$ & $\begin{array}{c}\text { C'ntr }^{\circ}{ }^{\wedge} \\
n=7\end{array}$ & $\begin{array}{l}+\left[5^{\circ} \mathrm{C}\right] \\
n=12\end{array}$ & $\begin{array}{c}+\left[36^{\circ} \mathrm{C}\right] \\
\mathrm{n}=11\end{array}$ & $\begin{array}{c}\text { C }^{\circ} n \text { r }^{\circ} \mathrm{I}+ \\
n=8\end{array}$ \\
\hline & \multicolumn{6}{|c|}{$\overline{\mathrm{X}}$} \\
\hline$\Delta \mathrm{T}_{0}-\mathrm{T}_{1}$ & $-14.50 \pm 17.16$ & $-19.25 \pm 11.15$ & $-5.63 \pm 25.28$ & $-8.25 \pm 12.49$ & $\begin{array}{c}-4.75 \pm 7.52 \\
* * * \\
*\end{array}$ & $-5.00 \pm 8.86$ \\
\hline$\Delta \mathrm{T}_{1}-\mathrm{T}_{2}$ & $\begin{array}{c}-32.25 \pm 18.60 \\
{ }^{*} \Delta T_{0}-T_{1}\end{array}$ & $\begin{array}{c}-0.3 \pm 0.7 \\
* \star \star \\
{ }^{*} 5^{\circ} \\
{ }^{* \star *} \Delta T_{0}-T_{1}\end{array}$ & $\begin{array}{c}+15.62 \pm 14.00 \\
* * \star \approx 5^{\circ} \\
* * \star \star 36^{\circ}\end{array}$ & $\begin{array}{c}-1.5 \pm 0.3 \\
{ }^{* *}{ }^{*} 5^{\circ} \\
{ }^{*} \Delta \mathrm{T}_{0}-\mathrm{T}_{1}\end{array}$ & $\begin{array}{c}-5.25 \pm 8.19 \\
* * * \$ 5^{\circ} \\
* * * \approx 36^{\circ}\end{array}$ & $\begin{array}{c}+9.38 \pm 9.43 \\
* * * 05^{\circ} \\
\quad * * 036^{\circ} \\
{ }^{*} \Delta \mathrm{T}_{0}-\mathrm{T}_{1} \\
\end{array}$ \\
\hline$\Delta T_{2}-T_{3}$ & $\begin{array}{c}+9.00 \pm 22.75 \\
{ }^{* * \star} \Delta T_{0}-T_{1} \\
{ }^{* * *} \Delta T_{1}-T_{2}\end{array}$ & $\begin{array}{c}+9.50 \pm 8.26 \\
{ }^{* *} \Delta \mathrm{T}_{0}-\mathrm{T}_{1} \\
{ }^{*} \Delta \mathrm{T}_{1}-\mathrm{T}_{2}\end{array}$ & $\begin{array}{c}-15.59 \pm 18.41 \\
* * 5^{\circ} \\
* * * \\
{ }^{*} 36^{\circ} \\
{ }^{* *} \Delta T_{1}-T_{2}\end{array}$ & $\begin{array}{c}+8.50 \pm 13.48 \\
{ }^{* * \star} \Delta \mathrm{T}_{0}-\mathrm{T}_{1} \\
{ }^{* *} \Delta \mathrm{T}_{1}-\mathrm{T}_{2}\end{array}$ & $+8.50 \pm 34.07$ & $\begin{array}{c}-5.63 \pm 6.78 \\
{ }^{*}+5^{\circ} \\
{ }^{*}+36^{\circ} \\
{ }^{*} \Delta \mathrm{T}_{1}-\mathrm{T}_{2} \\
\end{array}$ \\
\hline$\Delta \mathrm{T}_{3}-\mathrm{T}_{4}$ & $\begin{array}{c}+0.50 \pm 14.59 \\
{ }^{* * *} \Delta \mathrm{T}_{1}-\mathrm{T}_{2}\end{array}$ & $\begin{array}{c}-10.50 \pm 6.26 \\
{ }^{* * *} 5^{\circ} \\
{ }^{*} \Delta \mathrm{T}_{0}-\mathrm{T}_{1} \\
{ }^{* *} \Delta \mathrm{T}_{1}-\mathrm{T}_{2} \\
{ }^{* * *} \Delta \mathrm{T}_{2}-\mathrm{T}_{3} \\
\end{array}$ & $\begin{array}{c}+3.75 \pm 8.35 \\
* * * * 36^{\circ}\end{array}$ & $\begin{array}{c}+4.25 \pm 5.45 \\
{ }^{* * *} \Delta \mathrm{T}_{0}-\mathrm{T}_{1}\end{array}$ & $\begin{array}{c}-9.25 \pm 24.99 \\
{ }^{* * *}+5^{\circ} \\
{ }^{* *} \Delta \mathrm{T}_{2}-\mathrm{T}_{3}\end{array}$ & $\begin{array}{c}-7.50 \pm 8.45 \\
{ }^{* *}+5^{\circ} \\
{ }^{*} \mathrm{C} \\
{ }^{* *} \Delta \mathrm{T}_{1}-\mathrm{T}_{2} \\
\end{array}$ \\
\hline$\Delta T_{4}-T_{5}$ & $\begin{array}{c}-7.75 \pm 14.73 \\
{ }^{* *} \Delta T_{1}-T_{2} \\
{ }^{*} \Delta T_{2}-T_{3}\end{array}$ & $\begin{array}{c}+1.25 \pm 8.41 \\
{ }^{* *}{ }^{\circ} 5^{\circ} \\
{ }^{* * *} \Delta \mathrm{T}_{0}-\mathrm{T}_{1} \\
{ }^{*} \Delta \mathrm{T}_{2}-\mathrm{T}_{3} \\
{ }^{* * *} \Delta \mathrm{T}_{3}-\mathrm{T}_{4} \\
\end{array}$ & $\begin{array}{c}-7.50 \pm 7.07 \\
{ }^{* *} 36^{\circ} \\
{ }^{*} \Delta T_{1}-T_{2}\end{array}$ & $\begin{array}{c}0.3 \pm 5.62 \\
{ }^{* *} 5^{\circ} \\
{ }^{*} \Delta \mathrm{T}_{0}-\mathrm{T}_{1} \\
{ }^{* *} \Delta \mathrm{T}_{2}-\mathrm{T}_{3}\end{array}$ & $\begin{array}{c}-7.50 \pm 6.79 \\
{ }^{*}+5^{\circ} \\
{ }^{* *} \approx 36^{\circ} \\
{ }^{*} \Delta \mathrm{T}_{2}-\mathrm{T}_{3}\end{array}$ & $\begin{array}{c}+4.38 \pm 4.96 \\
* 05^{\circ} \\
{ }^{* *}+36^{\circ} \\
{ }^{* *}+\mathrm{C}\end{array}$ \\
\hline$\Delta T_{5}-T_{6}$ & $\begin{array}{c}+7.50 \pm 20.93 \\
{ }^{* *} \Delta \mathrm{T}_{0}-\mathrm{T}_{1} \\
{ }^{* \star} \Delta \mathrm{T}_{1}-\mathrm{T}_{2}\end{array}$ & $\begin{array}{c}+1.25 \pm 11.34 \\
{ }^{* * *} \Delta \mathrm{T}_{0}-\mathrm{T}_{1} \\
{ }^{*} \Delta \mathrm{T}_{2}-\mathrm{T}_{3} \\
{ }^{* * *} \Delta \mathrm{T}_{3}-\mathrm{T}_{4}\end{array}$ & $+4.38 \pm 18.02$ & $\begin{array}{c}+4.75 \pm 5.95 \\
{ }^{* \star} \Delta \mathrm{T}_{0}-\mathrm{T}_{1}\end{array}$ & $\begin{array}{c}+0.50 \pm 3.94 \\
{ }^{* * *}+5^{\circ}\end{array}$ & $\begin{array}{c}+3.75 \pm 5.18 \\
* \circ 36^{\circ}\end{array}$ \\
\hline$\Delta \mathrm{T}_{6}-\mathrm{T}_{7}$ & $\begin{array}{c}+2.50 \pm 12.51 \\
{ }^{*} \Delta \mathrm{T}_{0}-\mathrm{T}_{1} \\
{ }^{* * *} \Delta \mathrm{T}_{1}-\mathrm{T}_{2}\end{array}$ & $\begin{array}{c}+3.25 \pm 7.66 \\
{ }^{* * *} \Delta \mathrm{T}_{0}-\mathrm{T}_{1} \\
{ }^{* * *} \Delta \mathrm{T}_{3}-\mathrm{T}_{4}\end{array}$ & $+4.38 \pm 3.20$ & $\begin{array}{c}-3.50 \pm 4.01 \\
{ }^{*}{ }^{\circ} 5^{\circ} \\
{ }^{* * *} \Delta \mathrm{T}_{2}-\mathrm{T}_{3} \\
{ }^{*} \Delta \mathrm{T}_{3}-\mathrm{T}_{4} \\
{ }^{*} \Delta \mathrm{T}_{5}-\mathrm{T}_{6}\end{array}$ & $\begin{array}{c}+8.25 \pm 4.67 \\
{ }^{* * *}+5^{\circ} \\
{ }^{* *}{ }^{\circ} 36^{\circ} \\
{ }^{*} \Delta \mathrm{T}_{3}-\mathrm{T}_{4} \\
{ }^{*} \Delta \mathrm{T}_{4}-\mathrm{T}_{5} \\
\end{array}$ & $\begin{array}{c}0.00 \pm 7.07 \\
{ }^{*}+5^{\circ} \\
{ }^{* *}+36^{\circ}\end{array}$ \\
\hline$\Delta T_{7}-T_{8}$ & $\begin{array}{c}-10.00 \pm 12.14 \\
{ }^{* *} \Delta T_{1}-T_{2} \\
{ }^{*} \Delta T_{2}-T_{3} \\
{ }^{* * *} \Delta T_{5}-T_{6}\end{array}$ & $\begin{array}{c}-13.50 \pm 9.61 \\
{ }^{* *} \Delta \mathrm{T}_{1}-\mathrm{T}_{2} \\
{ }^{* *} \Delta \mathrm{T}_{2}-\mathrm{T}_{3} \\
{ }^{* *} \Delta \mathrm{T}_{4}-\mathrm{T}_{5} \\
{ }^{* * *} \Delta \mathrm{T}_{5}-\mathrm{T}_{6} \\
{ }^{* * *} \Delta \mathrm{T}_{6}-\mathrm{T}_{7}\end{array}$ & $\begin{array}{c}-8.75 \pm 7.91 \\
{ }^{*} \Delta \mathrm{T}_{1}-\mathrm{T}_{2}\end{array}$ & $\begin{array}{c}-1.25 \pm 3.19 \\
{ }^{* *} \approx 5^{\circ} \\
{ }^{* *} \Delta \mathrm{T}_{2}-\mathrm{T}_{3}\end{array}$ & $\begin{array}{c}-4.75 \pm 3.80 \\
* * * 5^{\circ} \\
* * * \approx 36^{\circ}\end{array}$ & $-1.25 \pm 13.30$ \\
\hline
\end{tabular}

BW - body weight; ${ }^{*} p<0.05,{ }^{* *} p<0.01,{ }^{* * *} p<0.001$. 
Considering the female rats from the cold group $\left(5^{\circ} \mathrm{C}\right)$, a decrease in body weight, by $8.25 \pm 12.49 \mathrm{~g}$ on average, was observed, remaining during the first two weeks, as in the male rats, but as early as experimental week 3 to the last week of this experiment an increase in body weight was recorded in relation to baseline values, with the highest increase, by $8.5 \pm 13.48 \mathrm{~g}$ on average, occurring at experimental week $3(p<0.001)$. In the female rats participating in swimming exercise training at thermal comfort temperature, a decrease in body weight was observed in relation to baseline values, but it was the highest after experimental week 4, by $9.25 \mathrm{~g}$ on average (Table 3). In the first three weeks of this experiment, no statistically significant differences were recorded in the observed trends between the experimental groups $\left(5^{\circ} \mathrm{C}\right.$ vs. $\left.36^{\circ} \mathrm{C}\right)$, whereas after week 4 of the experiment, until its end, there were differences in body weight changes between the groups $(p<0.05)$, with the female rats from the cold group $\left(5^{\circ} \mathrm{C}\right)$ demonstrating an increasing trend in their body weight and those from the thermal neutral group $\left(36^{\circ} \mathrm{C}\right)$ a decreasing trend. In the case of the control group of female rats, their body weight remained at a comparable level in successive weeks of this experiment. Only experimental week 2 , as in the case of male rats, was characterised by an increase in body weight compared to other weeks of the experiment $\left({ }^{*} \Delta T_{1}-T_{2}\right)$, but the final weight of the rats was comparable to its baseline value. At experimental week 2 , highly significant differences in body weight changes were recorded between the test groups and the control group. During the experiment, changes in the body weight of rats in the control group were much smaller than in the case of the test groups (Table 2).

When comparing the nature of changes in the body weight of rats exposed to swimming exercise training in cold water, attention should be paid to their dependence on sex. There were statistically significant changes in the nature of changes in body weight between male rats and female rats of the cold group $\left(5^{\circ} \mathrm{C}\right)$ as early as experimental week 2 until the end of the experiment $(p<0.001)$. Interestingly, the females exposed to swimming exercise training at $5^{\circ} \mathrm{C}$ were the only group in which an increase in body weight occurred during experimental week $8 \mathrm{in}$ relation to baseline values. The body weight of all rats from the groups swimming at $36^{\circ} \mathrm{C}$ was decreasing, being more significant in the male rats ( $28 \pm 22.68$ vs. $14 \pm 24.72$, Table 2 ).

The resting rectal temperature in the rats of respective groups did not differ significantly and amounted to $35.81 \pm 2.32^{\circ} \mathrm{C}$ on average. When analysing the thermal response of rats to swimming exercise sessions, a transient decrease in their rectal temperature was observed only in the group of animals swimming at $5^{\circ} \mathrm{C}$ (by $3.8^{\circ} \mathrm{C}$ on average; $p<0.05$ ), whereas no significant change in their resting rectal temperature was showed after the end of the experiment.

\section{Discussion}

In the presented study, an attempt was made to evaluate the possible occurrence of adaptive changes of an insulative nature in rats exposed to swimming exercise training at $5^{\circ} \mathrm{C}$. Under such circumstances, changes occur in the dynamics of microcirculation and metabolic responses, as well as in the dynamics of collateral circulation. Cold and physical exercise are stress factors that stimulate the sympathetic system, adrenal glands and thyroid gland, stimulating metabolism and, at the same time, increasing the quantity of food consumed. Body weight depends on energy intake, energy consumption and digestion (Knopper, Boily, 2000; Powell et al., 2002; Ernest, 2005). A seasonal change in body weight results from adaptation to energy intake and energy demand in many small mammals (Wang, Wang, Wang, 2001; Speakman, 2003). A change in body weight is an adaptive response in the ability to adapt to cold environment in mammals (Swanson, 2001). The response of small mammals to cold stress differs, as is the case of Dicrostonyx groenlandicus and Mesocricetus auratus, the body weight of which 
increased during cold acclimation (Nagy, Negus, 1993; Janský, Haddad, Pospísilová, Dvorák, 1986). However, the body weight of Apodemus sylvaticus and Acomys cahirinus was not affected by cold acclimation (Klaus, Heldmaier, Ricquier, 1988; Khokhlova, Krasnov, Shenbrot, Degen, 2000; Gunduz, 2002); on the contrary, the body weight of Phodopussungorus, Microtusochrogaster, M. pennslvanicus and Clethrionomysglareolus decreased during cold acclimation (Klaus et al., 1988; Wiesinger, Heldmaier, Buchberger, 1989; Voltura, Wunder, 1998; Wang, Wang, 1990). In the study by Arnold, Richard (1987), cold exposure had no additional effect on body composition in physically active rats. Compared to rats trained at $24^{\circ} \mathrm{C}$, exercised cold-exposed animals did not utilise more of their fat or protein stores in providing substrate for exercise. Interestingly, although a $5^{\circ} \mathrm{C}$ exposure and exercise were estimated to produce similar energy expenditures, both exercised groups of rats had significantly lower body fat gains. It seems probable that the greater energy intake of sedentary cold-exposed rats accounted for most of their extra fat reserve. Appetite suppression has been observed previously in exercised male rats (Arnold, Richard, 1987; Richard, Arnold, Lleblanc, 1986) and, since this phenomenon has not been observed in exercised female rats, is believed to be linked to sex hormones.

Some recent work by Hoffman-Goetz, German (1986) has suggested that physical exercise improves cold tolerance in aged mice, although the mechanism behind the improvement remains unexplained. The study by Richard et al. (1986) has indicated that brown adipose tissue capacity for non-shivering thermogenesis is unimproved by exercise training. However, exercise training, by increasing insulin sensitivity (Berger et al., 1979; Mondon, Dolkas, Reaven, 1980), may prevent the age-related increase in tissue insulin resistance and therefore aid in preserving the brown adipose tissue thermogenesis. That is, as insulin resistance has been suggested to be a possible cause of impaired brown adipose tissue thermogenesis in obese mice (Mercer, Trayhurn, 1984), exercise training, by decreasing insulin resistance, may actually improve cold tolerance. Further work is needed to understand the improved tolerance to cold in exercised rodents. It appears that metabolic heat production in exercised cold-exposed rats was sufficient to offset the cold stress without which increased brown adipose tissue non-shivering thermogenic capacity cannot occur (Arnold, Richard, 1987).

Smith, Roberts (1964) have demonstrated that multilocular brown adipose tissue in the rat is shown to increase in both respiratory rate and mass, in vitro, during cold acclimation. By vascular convection the resulting heat is directly conducted to the thoracocervical regions of the heart, the spinal cord and other thoracic organs. The vasculature is so arranged as to exercise a fine order of thermogenic control over the brown fat and temperature of the peripheral venous returns to the thorax, facilitated in part by a "reverse" type of countercurrent heat exchange apparently not previously described. In humans, acclimatisation to cold develops over the period of about 10 days, and in the essential change is an insulative, hypothermic type of response. This reflects the nature of most occupational and athletic exposures to cold. Nevertheless, with more persistent exposure to cold, humans can seemingly develop the humoral type of acclimatisation described in small mammals, with an increased efficiency of noradrenaline or thyroxine. Using of winter sport may be method of treating obesity due to associated mobilisation of free fatty acids. In men, a combination of temperate exercise and facial cooling induces a significant fat loss over a 1- to 2-week period, with an associated proteinuria, ketonuria and increased body weight. Current limitations for the clinical application of such treatment include doubts regarding appropriate environmental conditions, concern over possible pathological responses to cold, and suggestions of a less satisfactory fat mobilisation in female patients (Adams, Heberling, 1958). William et al. (1992), when examining sex differences in response to physical exercise conducted in cold water environment, demonstrated their dependence on the content of lean body mass $(63.5 \mathrm{~kg}$ 
in men vs. $49.5 \mathrm{~kg}$ in women). This difference in lean tissue favours heat conservation by men compared to women during rest (Veicsteinas, Ferretti, Rennie, 1982). Also, at low absolute exercise intensities it is likely that for men, compared to women, a larger amount of muscle tissue remains minimally perfused. This would provide men with lager resistance to heat that moves from the core to the skin surface during exercise in cold water. For women, even mild exercise appears to remove the insulation provided by muscle mass. Consequently, the added heat generated by exercise is offset by the reduction in insulation (William et al., 1992). Mozaffarieh et al. (2010) found that women had significantly higher TDCE (thermal discomfort with cold extremities) scores than men. These results confirm that nearly every third woman between 20 and 40 years suffers from cold extremities, with men suffering 4.5 times less frequently (Kräuchi et al., 2008). Numerous investigators have reported that women have colder mean skin temperatures during rest in cold air than men (Cunningham, Stolwijk, Wenger, 1978; Wyndham et al., 1964; Wagner, Horvath, 1985). While this has been imputed to differences in body fat by some authors (Wyndham et al., 1964; Wagner, Horvath, 1985), others have not been able to prove a correlation between fatness and mean skin temperature (Stevens, Graham, Wilson, 1987). Facultative interactions between metabolic responses to cold and physical fitness remain controversial. However, it is obvious that short term cold exposure induces a humble increase of physical working capacity. Long term effects of cold upon fitness are probably mediated largely through associated changes in habitual physical activity (Shepard, 1985). Regular physical activity not only increases energy expenditure directly, but also modulates gene expression patterns of metabolic regulators. Gene expression patterns induced by a sedentary lifestyle result in metabolic patterns that are the precursors of metabolic diseases prevalent among humans. Cold exposure combined with exercise combined with promotes uncoupling of oxidative phosphorylation by increasing the expression of UCP1 in BAT. Increased expression of UCP1 increases the proportion of energy derived from fatty acid oxidation that is released as heat, seldom being deposited as white adipose tissue. This provides an important entrance by which exercise simplify increased energy expenditure and counteracts obesity. Obesity, although complicated by social and cultural influences, is due to an excess of energy intake over energy expenditure. Brown adipose tissue therefore plays an important role in the energy balance of the whole organism including adult humans, but exercise is a necessary condition for this role to be realised (Seebacher, Glanville, 2010).

We examined a suitable swimming exercise programme at different water temperatures that could induce changes in body weight in 15-month-old rats. In all test groups, we observed the effect of physical exercise and ambient temperature on changes in body weight. In the male rats, swimming exercise training at low temperature induced a significance decrease in body weight, which is linked to energy expenditure on exercise and thermoregulation processes. In the case of swimming at $36^{\circ} \mathrm{C}$, a decrease in body weight resulted solely from physical exercise, which was also observed in the female rats swimming at the same temperature. The fact that in the female rats swimming at $5^{\circ} \mathrm{C}$ a decrease in body weight was observed for the first two weeks, and then its increase until the end of the experiment, seems to be interesting. Davies, Packer, Brooks (1987) have observed that female rats are known to maintain body weight better than male rats. It has been reported that a prolonged exposure to cold raises the metabolic rate in mammals, which leads to increased hypotrophy of metabolically active tissues, like for example brown adipose tissue (BAT), liver, kidneys, small intestine, and heart (Krebs, 1950; McDevitt, Speakman, 1994; Konarzewski, Diamon, 1994). Another possible type of adaptive changes in response to cold is the hypothermic type when there is a decrease in body temperature and the body adapts to a lower temperature. Although our results indicate a substantial decrease in the body temperature of rats exposed to a single swimming 
exercise in water at $5^{\circ} \mathrm{C}$, no such adaptive changes were showed in the test rats as a consequence of 8-week-long swimming exercise training in cold water.

\section{Conclusions}

Inter-sexual difference in body weight changes being observed during an 8-week-long experiment indicate that adaptive mechanism of an adaptive nature, in the form of increased accumulation of adipose tissue or hypertrophy of metabolically active tissues, developed earlier in female rats, which was not observed in male rats, despite exposure to cold to the same extent. The next stage of our research will be to estimate selected metabolic parameters and oxidant-antioxidant equilibrium of rats in order to evaluate the extent of "cold shock" responses to physical exercise, depending on the temperature at which it is performed.

\section{Acknowledgements}

Study was supported by Pomeranian Medical University in Szczecin No FSN-318-09/13.

\section{References}

Adams, T., Heberling, E.J. (1958). Human physiological responses to a standardized cold stress as modified by physical fitness. J Appl Physiol., 13 (2), 226-230.

Agrawal, A., Jaggi, A.S., Singh, N. (2011). Pharmacological investigations on adaptation in rats subjected to cold water immersion stress. Physiol Behav, 103, 321-329.

Akhalaya, M.Y., Platonov, A.G., Baizhumanov, A.A. (2006). Short-term cold exposure improves antioxidant status and general resistance of animals. Bull Exp Biol Med, 141, 26-29.

Arnold, J., Richard, D. (1987). Exercise during intermittent cold exposure prevents acclimation to cold rats. J. Physiol., 390, 45-54.

Benarroch, E.E. (2007). Thermoregulation: recentconcepts and remainingquestions. Neurology, 69, 1293-1297.

Berger, M., Kemmer, F.W., Becker, K., Herberg, L., Schwenen, M., Gjinavci, A., Berchtold, P. (1979). Effect of physical training on glucose tolerance and on glucose metabolism of skeletal muscle in anaesthetized normal rats. Diabetologia, 16, 179-184.

Block, B.A. (1994). Thermogenesis in muscle. Ann. Rev. Physiol., 56, 535-577.

Cannon, B., Nedergaard, J. (2004). Brown adipose tissue: function and physiological significance. Physiol Rev, 84, 277-359.

Chukroun, M.L., Varene, P. (1990). Adjustments in oxygen transport during head-out immersion in water at different temperatures. J Appl Physiol, 68, 1475-1480.

Cunningham, D.J., Stolwijk, J.A., Wenger, C.B. (1978). Comparative thermoregulatory responses of resting men and women. J Appl Physiol, 45, 908-915.

Davies, K.J., Packer, L., Brooks, G.A. (1987). Biochemical adaptation of mitochondria, muscle, and whole-animal respiration to endurance training. Arch Biochem Biophys, 209, 539-554.

Ernest, S.K.M. (2005). Body size, energy use, and community structure of small mammals. Ecology, 86 (6), 1407-1413.

Foster, D.O., Frydman, M.I. (1978). Non-shivering thermogenesis in the rat. II. Measurements of blood flow with microspheres point to brown adipose tissue as the dominant site of the calorigenesis induced by noradrenaline. Can. J. Physiol. Pharm., 56, 110-122.

Gunduz, B. (2002). Effects of photoperiod and temperature on growth and reproductive organ mass in adult male Mongolian gerbils Meriones unguicu-latus. Turk. J. Biol., 26, 77-82.

Hoffman-Goetz, L., German, E. (1986). Cold acclimation and exercise as modulators of age associated hypothermia in mice. In: K. Cooper, P. Lomax, E. Schonbaum, W.L. Veale (eds.), Homeostasis and Thermal Stress, 6th International Symposium on the Pharmacology of Thermoregulation (pp. 46-48). Jasper, Alta: Karger.

Janský, L., Haddad, G., Pospísilová, D., Dvorák, P. (1986). Effect of external factors on gonadal activity and body mass of male golden hamsters (Mesocricetus Auratus). J. Comp. Physiol. B, 156, 717-725.

Keatinge, W.R. (1961). The effect of work and clothing on the maintenance of the body temperature in water. Q J Exp Physiol Cogn Med Sci, 46, 69-82. 
Khokhlova, I., Krasnov, B.R., Shenbrot, G.I., Degen, A.A. (2000). Body mass and environment: a study in Negev rodents. Israel J. Zool., $46,1-13$.

Klaus, S., Heldmaier, G., Ricquier, D. (1988). Seasonal acclimation of bank voles and thermogenic properties of brown adipose tissue mitochondria. J. Comp. Physiol. B, 158, 157-164.

Knopper, L.D., Boily, P. (2000). The energy budget of captive Siberian hamsters Phodopus sungorus exposed to photoperiod changes: mass loss is caused by a voluntary decrease in food intake. Physiol. Biochem. Zool., 73 (4), 517-522.

Kolettis, T.M., Kolettis, M. (2003). Winter swimming: healthy or hazardous? Evidence and hypotheses. Med Hypotheses, 61, 654-656.

Konarzewski, M., Diamon, J. (1994). Peak sustained metabolic rate in cold-stressed mice. Physiol. Zool., 67, 1186-1212.

Kozak, L.P., Harper, M.E. (2000). Mitochondrial uncoupling proteins in energy expenditure. Annu Rev Nutr, 20, 339-363.

Kräuchi, K., Fontana Gasio, P., Vollenweider, S., Von Arb, M., Dubler, B., Orgül, S., Flammer, J., Zemp Stutz, E. (2008). Cold extremities and difficulties initiating sleep: evidence of co-morbidity from a random sample of a Swiss urban population. J Sleep Res, 17, 420-426.

Krebs, H.A. (1950). Body size and tissue respiration. Biochem. Biophys. Acta, 4, 249-269.

Lubkowska, A., Banfi, G., Dołegowska, B., d'Eril, G.V., Łuczak, J., Barassi, A. (2010a). Changes in lipid profile in response to three different protocols of whole-body cryostimulation treatments. Cryobiology, 61 (1), 22-26.

Lubkowska, A., Szygula, Z., Klimek, A.J., Torii, M. (2010b). Do sessions of cryostimulation have influence on white blood cell count, level of IL6 and total oxidative and antioxidative status in healthy men? Eur J Appl Physiol, 109 (1), 67-72.

Lubkowska, A., Dołęgowska, B., Szyguła, Z. (2012). Whole-Body Cryostimulation - Potential Beneficial Treatment for Improving Antioxidant Capacity in Healthy Men - Significance of the Number of Sessions. PLoS ONE, 7 (10), e46352.

Lubkowska, A., Dołęgowska, B., Szyguła, Z., Bryczkowska, I., Stańczyk-Dunaj, M., Sałata, D., Budkowska, M. (2013). Winter-swimming as a building-up body resistance factor inducing adaptive changes in the oxidant/antioxidant status. Scandinavian Journal of Clinical \& Laboratory Investigation, 73 (4), 315-325.

McDevitt, R.M., Speakman, J.R. (1994). Central limits to sustainablemetabolic rate have no role in cold-acclimation of the shorttailedfield vole (Microtus agrestis). Physiol. Zool., 67 (5), 1117-1139.

Mercer, S.W., Trayhurn, P. (1984). The development of insulin resistance in brown adipose tissue may impair the acute cold-induced activation of thermogenesis in genetically obese (ob/ob) mice. Bioscience Reports, 4, 933-940.

Mondon, C.E., Dolkas, C.B., Reaven, G.M. (1980). Site of enhanced insulin sensitivity in exercise-trained rats at rest. American Journal of Physiology, 239, 169-177.

Moran, D.S., Menda, I.L. (2002). Core temperature measurement: methods and current insights. Sports Med, 32, 879-885.

Mozaffarieh, M., Gasio, P.F., Schötzau, A., Orgül, S., Flammer, J., Kräuchi, K. (2010). Thermal discomfort with cold extremities in relation to age, gender, and body mass index in a random sample of a Swiss urban population. Population Health Metrics, 8 (1), 17. DOI: 10.1186/1478-7954-8-17.

Nagy, T.R., Negus, N.C. (1993). Energy acquisition and allocation in male collared lemmings Dicrostonyx greenlandicus: effects of photoperiod, temperature, and diet quality. Physiol. Zool., 66 (4), 537-560.

Powell, C.S., Blaylock, M.L., Wang, R., Hunter, H.L., Tohanning, G.L., Nagy, T.R. (2002). Effects of energy expenditure and UCPI on photoperiod induced weight gain in collared lemmings. Obesity Res., 10 (6), 541-550.

Richard, D., Arnold, J., Lleblanc, J. (1986). Energy balance in exercise-trained rats acclimated at two environmental temperatures. Journal of Applied Physiology, 60, 1054-1059.

Richard, D., Picard, F. (2011). Brown fat biology and thermogenesis. Front Biosci (Landmark Ed), 16, 1233-1260.

Sellers, E., Scott, J., Thomas, N. (1954). Electrical activity of skeletal muscle of normal and acclimatized rats on exposure to cold. Am. J. Physiol., 177, 372-376.

Shepard, R.J. (1985). Adaptation to Exercise in the Cold. Sports Medicine, 2 (1), 59-71.

Seebacher, F., Glanville, E.J. (2010). Low Levels of Physical Activity Increase Metabolic Responsiveness to Cold in a Rat (Rattus fuscipes). PLoS ONE, 5 (9), e0013022.

Smith, R.E., Roberts, J.C. (1964). Thermogenesis of brown adipose tissue in cold-acclimated rats. American Journal of Physiology, 206, 143-148.

Speakman, J.R., Ergon, T., Cavanagh, R., Reid, K., Scantlebury, D.M., Lambin, X. (2003). Rest and daily energy expenditures of freeliving field voles are positively correlated but reflect extrinsic rather than intrinsic effects. PNAS, 100 (24), 14057-14062. 
Stevens, G.H., Graham, T.E., Wilson, B.A. (1987). Gender differences in cardiovascular and metabolic responses to cold and exercise. Can J Physiol Pharmacol, 65, 165-171.

Straburzyńska-Lupa, A., Straburzyński G. (2008). Hydrotherapy. In: A. Siedlecka (ed.), Physiotherapy with elements of clinical vol. 1 (pp. 86-271). Warszawa: PZWL.

Swanson, D.L. (2001). Are summit metabolism and thermogenic endurance correlated in winter-acclimatized passerine birds? Comp. Physiol. B, 171, 475-481.

Teległów, A., Bilski, J., Marchewka, A., Głodzik, J., Jaśkiewicz, J., Staszek, P. (2008). Characteristics of the body’s response to exercise in cold water. Medicina Sportiva Practica, 9 (4), 66-72.

Tsopanakis, C., Tesserommatis, C. (1991). Cold swimming stress: Effects on serum lipids, lipoproteins and LCAT activity in male and female rats. Pharmacology Biochemistry and Behavior, 38 (4), 813-816.

Veicsteinas, A., Ferretti, G., Rennie, D.W. (1982). Superficial shell insulation in resting and exercising men in cold water. J Appl Physiol, 52, 1557-1564.

Villarin, J.J., Schaeffer, P.J., Markle, R.A., Lindstedt, S.L. (2003). Chronic cold exposure increases liver oxidative capacity in the marsupial Monodelphis domestica. Comp Biochem Physiol A Mol Integr Physiol., 136 (3), 621-30.

Voltura, M.B., Wunder, A. (1998). Effects of ambient temperature, diet quality, and food restriction on body composition dynamics of the prairie vole Microtus ochrogaster. Physiol. Zool., 71 (3), 321-328.

Wagner, J.A., Horvath, S.M. (1985). Influences of age and gender on human thermoregulatory responses to cold exposures. J Appl Physiol, 58, 180-186.

Wang, D.H., Wang, Z.W. (1990). Seasonal changes of nonshivering thermogenesis (NST) in Plateau Pikas (Ochotna curzoniae) and Root Voles (Microtus oeconomus). Acta Theriologica Sinica., 10, 40-53.

Wang, Y.S., Wang, Z.W., Wang, D.H. (2001). Effects of temperature and photoperiod on maximum metabolic rates in plateau pikas and root voles. Zool. Res., 22 (3), 200-204.

Wiesinger, H., Heldmaier, G., Buchberger, A. (1989). Effect of photoperiod and acclimation on nonshivering thermogenesis and GDPbinding of brown fat mitochondria in Djungarian hamster, Phodopus s. sungorus. Eur. J. Physiol., 413, 667-672.

William, D., McArdle, W.D., Toner, M.M., Magel, J.R., Spina, R.J., Pandolf, K.B. (1992). Thermal responses of men and women during cold-water immersion: influence of exercise intensity. Eur J Appl Physiol, 65, 265-270.

Wilmore, J.H., Costill, D.L. (2008). Exercise in hot and cold environments: Thermoregulation. In: J.H. Wilmore, D.L. Costill, W.L. Kenney (eds.), Physiology of Sports and Exercise (pp. 52-277). Champaign: Human Kinetics.

Wyndham, C.H., Morrison, J.F., Williams, C.G., Bredell, G.A.G., Peter, M.J.E., Von Rahden, M.J.E., Holdsworth, L.D., Van Graan, C.H., Van Rensburg, A.J., Munro, A. (1964). Physiological Reactions To Cold Of Caucasian Females. J Appl Physiol, 19, 877-880.

Cite this anticle aS: Bryczkowska, I., Baranowska-Bosiacka, I., Lubkowska, A. (2017). Effect of Repeated Cold Water Swimming Exercise on Adaptive Changes in Body Weight in Older Rats. Central European Journal of Sport Sciences and Medicine, 18 (2), 77-87. DOI: 10.18276/cej.2017.2-08. 
